GLOBAL JOURNAL OF SOCIAL SCIENCES VOL 19, 2020: 53-62

COPYRIGHT@ BACHUDO SCIENCE CO. LTD PRINTED IN NIGERIA. ISSN 1596-6216

53 www.globaljournalseries.com; Info@globaljournalseries.com

\title{
ENGAGING MEDIA ADVOCACY ON SELF-LITTERING OF THE ENVIRONMENT IN NIGERIA
}

AKPOGHIRAN, IDAMAH PATRICK

(Received 30 April 2020, Revision Accepted 31 August 2020)

\begin{abstract}
Self-littering of the environment has become habit among many Nigerians. People on daily basis littered the environment with all kinds of wastes, and this has affected the aesthetic beauty of the environment.. The study examines media advocacy on self-littering of the environment. The main objective of the study was to determine how media advocacy can help to discourage self-littering of the environment. Questionnaire was used as instrument for data collection. A total of 384 respondents were sampled in Benin City, Edo state, Nigeria on the subject matter. The results showed that media advocacy can help to discourage self-littering with the adoption of various communication channels. Inhabitants' are aware that they littered the environment with dirt but change in behaviour is needed. Consistent media advocacy can bring about that needed change to stop self-littering of the environment.
\end{abstract}

KEYWORDS: Environment; Habit; Littering; Media advocacy; Self-Littering

\section{INTRODUCTION}

Self-littering of the environment is a common environmental practice and habit in Nigeria. Scholars in environmental management have lamented over the sorry state of littering of the environment with several kinds of wastes. For example, Eneji; Eneji; Ngoka, and Abang, (2017) were of the view that human health has to do with the state of the environment. Anozie (2017) says littering of the environment is as a result of bad habit. Freijea; Nasera; and Abdullab (2019) note that littering in public places is a problem that has adverse environmental and socioeconomic impacts and with several implications on human health and the integrity of the environment. Oluyinka and Balogun (2013) observed that throwing litter on bare ground increases the time, money, and human resources that government, community, and individuals have to spend on environmental sanitation and clean up activities.
Oteng-Ababio (2012) notes poor attitudes and lack of concern about environmental issues as result of self-littering of the environment. A study on attitude towards littering as conducted by Oluyinka and Balogun (2013) showed that there was a negative influence of self-monitoring on attitude towards littering but no significant influence on responsible environmental behaviour was obtained. In addition, attitude towards littering had a negative influence on responsible environmental behaviour. As the study showed, attitude towards littering can reinforce the part of influence of self-monitoring on individual responsible environmental behaviour

As habit of throwing trash or any visible solid waste improperly in the wrong places (Freijea et. al; 2019), Nigerians on daily basis consciously and unconsciously littered the environment with all kinds of wastes when they are walking, eating,

\footnotetext{
Akpoghiran, Idamah Patrick, Department of Mass Communication Western Delta University, Oghara, Nigeria
}

(C) 2020 Bachudo Science Co. Ltd. This work is licensed under Creative Commons Attribution 4.0 International license. 
reading, talking, buying and celebrating. Many Nigerians do not have proper littering habit or culture. Some throw waste or used items from moving vehicle while some littered the ground with empty sachet water, banana peels, bottle or table water, and cob of maize, papers and all sorts of dirt in a manner that is inappropriate. This happens in schools, colleges, shops, on the streets, churches, motor-parks and other public places.

Littering of the environment is very much tied to copy or imitate 'what others do'. For example, as a child grows he/she sees how adult littered the environment. The child thinks that the act is the right thing to do. Some adults still believe that there is nothing wrong in littering of the environment. In Nigeria, it is accepted by many as 'normal act or practice'. The child grow up with the same thinking, beliefs and it becomes a habit believing that there is nothing wrong with it.. This is why littering of the environment has become 'unconscious culture or habit' to some Nigerians. By this, self littering becomes a belief and habit (Mamady, 2016). This also affects a whole community (Yoada; Chirawurah; \& Adongo, 2014).

The concept of media advocacy had always been employed on social and health studies (Wallack, 1994). Media advocacy have largely been concerned with public health, public policy (Dorfman \& Krasnow, 2014; Fayoyin, 2014; Eze, 2014), propaganda tool for political organizations (Waibord, 2006), and campaign against tobacco smoking and alcohol control (US Department of Health, 1988). Studies on media advocacy have also been on child rights issues (Oyesomi; Oyero; \& Okorie, 2014), participatory agriculture (Abga; Abang; \& Ugor, 2017), climate change (Okaka \& Nagasha, 2017), election, family planning, water development (Eze, 2014), environmental management and so on. Media advocacy on self-littering of the environment becomes imperative in recent times because it is bad environmental habit (Anozie, 2017) that is widely recognized as an ongoing global problem (Freijea; et. al., 2019). Self littering also has negative influence on responsible environmental behaviour (REB) (Oluyinka \& Balogun, 2013), and on a whole, litter may degrade the aesthetic value of public places and it may pose a health hazard for humans and other living organisms (Freijea; et. al., 2019).
While there are different approaches adopted by the appropriate authorities to stop self littering such as imposing fines and sanctions when caught, conducting cleaning campaigns, raising public awareness, locating well-designed trash cans in public places (Wever, Onselen, Silvester, \& Boks, 2010), this present study adopts Environmental Media Advocacy (EMA) as environmental education approach to prevent or stop self littering of the environment. Environmental education is required to change littering habit. Environmental education has to do with a change of attitude, norms, values, beliefs, and awareness toward a friendly environment (Dung; Mankilik, \& Ozoji, 2017). According to the authors, individual needs a good knowledge base in environmental education. To them, environmental knowledge is all about gaining a variety of experiences and acquiring a basic understanding of the environment and its associated problems. Environmental education through the media is needed to stop irresponsible environmental behaviour such as self-littering, dumping refuse at unapproved places, indiscriminate bush burning, and unnecessary tree falling, open defecation and so on, and to promote responsible environmental behaviour.

Consequently, the aims of this present study among others are to examine respondents' personal awareness on self-littering of the environment; to find out the main reasons behind self-littering of the environment and find out media advocacy strategies in discouraging of self-littering of the environment in Nigeria. The study will provide valuable contributions to existing theories, concepts, studies practice and researches on self-littering habit. Thus, it may provide valuable information about causes and possible solutions for self-littering in Nigeria. The study is significant because it will give understanding of the need to campaign against self-littering of the environment.

\section{THEORETICAL FRAMEWORK FOR ANALYSIS}

The study is anchored on Theory of Reasoned Action (TRA). This theory was developed by Ajzen and Fishbein in 1980 in determining individual attitude towards an intention (Akpoghiran \& Okoro, 2017). The TRA views a person's intention to perform (or not perform) as the immediate determinant of the action. The primary purpose of the TRA is to understand an individual's actions is guided by motivation or 
intention, beliefs and attitude. These factors determine our intended and performed actions. According to the theory, intention to perform certain behaviour precedes the actual behaviour (Madden, \& Azjen, 1986). This intention is known as behavioural intention and comes as a result of a belief that performing the behaviour will lead to a specific outcome. The theory of reasoned action suggests that stronger intentions lead to increased effort to perform the behaviour, which also increases the likelihood for the behaviour to be performed. The beliefs that underlie a person's attitude towards the behaviour are termed behavioural beliefs, and those that underlie the subjective norm are termed normative beliefs (Ajzen \& Fishbein, 1980, as cited in Akpoghiran \& Okoro, 2017).

Studies have used the theory of reasoned action as a framework for understanding and explaining environmental behaviours (Madden. \& Ajzen, 1986;. Gamba \& Oskamp, 1994; Ifegbesan 2009). Drawn from the theory of planned behaviour, the theory of reasoned action has been widely used in environmental behaviour to explain that people's perceptions of the environment are related to their actions. Attitude towards the environment can be influenced by environmental news. The theory of reasoned action is thus a very powerful and predictive theory for explaining reason for human behaviour. The theory is anchored on motivation, intention, attitude and beliefs. Beliefs seem to be a strong indicator or factor for littering of waste. When constructive belief for environmental management is built, it leads to positive waste disposal practice. This is why Mamady (2016), posits that increasing knowledge can foster positive attitudes and build safe practices. The above implies that habit or culture of littering is tied to attitude, which later becomes habit. Eneji et. al. (2017) argued that people who litter the environment have non-chalant attitude towards waste disposal. This also suggests that attitude underline the theory of reason action.

Invariably, media advocacy can help us to 'reasoned our action' in line with environmental best practices. Media advocacy can help change our poor environmental beliefs and actions and help to stop littering habit. Akeh and Shehu (2018) believe that awareness on environmentally friendly ways of waste disposal will go a long way in checking indiscriminate waste disposal and littering habit. This is why media education is important to help stop littering habit. The radio for example, is cheap and portable and can reach millions of audience. Akpan (2006) believes that before the internet and the social media, radio exercises social control more compellingly than any other medium. It challenges these primary agents of family and school because of the coveted attributes it has. The attributes of the broadcast media are capable of shaping and moulding opinions and appealing to senses as far as selflittering of the environmental is concerned. Therefore, media advocacy are capable of "shaping social norms and values, influence people's decisions in manners that promote a more environmentally sustainable society" (Nwabueze, 2007:49). Media advocacy in different platforms can play a significant part in promoting and accelerating changes in attitudes. Also, when an inhabitant adopts reasons and actions that are in conformity with environmental values, and avoid actions that are harmful to the environment, then, self-littering would be reduced or stopped.

Also, media advocacy as applicable to the theory reasoned action points to responsible environmental behaviour, which means actions taken by an individual or a group of individuals to do what is right in order to protect the environment. Environmental media advocacy can be directed to stop self-littering of the environment.

\section{MATERIALS AND METHOD}

The study adopted the cross-sectional survey research design. Research respondents of this type cut across different parts of the country. Specifically, the participants were drawn from Benin City. Eight (8) research assistants from the Western Delta University, Oghara, Delta sstate, Nigeria who resides in Benin City were selected to administer the copies of the questionnaire in Benin City covering areas like Aduwawa; Ekenwa; G.R.A; Ikpoba hill; Oko/Airport road; Ugbowo; Upper Sakpoba area; and Sapele road. This was done during the long second semester holidays, 2019 (August- September). The population of Benin City as at the 2006 National Population Census was 1, 495,800 (see www.nationalpopulationcommission.ng ) but by projection of 2.3 growth rate, the population in 2019 is $1,749,316$. The Fisher and Lee sample size of 384 was adopted. This is used for a population size that exceeds 10,000 . The copies 
of the questionnaire (384) were equally shared among the 8 research assistants. Each got 48 copies. The instrument for data collection was designed to ascertain Media Advocacy on SelfLittering Habit (MASLH). MASLH was designed on a five-point Likert scale ranging. Similar scale has been used by Dung; Mankilik; and Ozoji (2017) in determining college students' knowledge and attitudes towards solid waste management in north central zone of Nigeria.

\section{Presentation of Results in Tables}

Table 1: Respondents' Personal Awareness on Self-Littering of the Environment

Items
Categories (n-377)
Are you aware that..........?

That you littered the environment with waste

That you consciously throw used items on the ground after using them

That you do not throw waste on trash can or container after use

That you throw waste or used items from moving vehicle

That self-littering of the environment is a regular act to you

That I litter the ground because there are paid workers to clean it up

That self-littering is a bad environmental habit

That self-littering can constitute environmental hazards like diseases

That the more I littered the environment the more I do harm to it

That self-littering deface the aesthetic beauty of the environment

That I have the duty to stop self-littering and keep the environment clean

That I am expected to tell others to stop self-littering

That media advocacy is necessary to discourage self-littering
(Option) I am not aware

\section{(Option) \\ am aware}

$\begin{array}{llll}\text { Freg. } & \% & \text { Freg. } & \% \\ 167 & 44.3 & 210 & 55.7 \\ 253 & 67 & 124 & 33 \\ 235 & 62 & 143 & 38 \\ 291 & 77 & 86 & 23 \\ 277 & 73 & 100 & 27 \\ 287 & 76 & 90 & 24 \\ 81 & 21 & 296 & 79 \\ 79 & 21 & 298 & 79 \\ 91 & 24 & 286 & 76 \\ 101 & 27 & 276 & 73 \\ 67 & 18 & 310 & 82 \\ 121 & 32.1 & 256 & 67.9 \\ 271 & 72 & 106 & 28\end{array}$

The table showed respondent personal awareness of self-littering of the environment 
Table 2: Probable Causes/Reasons of Littering as Waste Habit Items

Self littering of waste on the environment is as a SA result of............

Poor environmental culture from home.

Unconscious about the healthy environment.

Poor environmental management attitude

Low level of environmental education

Poor and inconsistent media sensitization

Poor environmental communication culture

Dirty environmental culture

Rapid population growth

Rapid urban development

Volume of waste generated

Low level of formal education

Age factor

Eating habit

Ignorance of a healthy environment

No self-correction mechanism

Poor media advocacy campaigns

No public notice correction mechanism

Mean point/benchmark:3.00

$\begin{array}{rcccccc}\text { SA } & \text { A } & \text { UD } & \text { DA } & \text { SD } & & \text { Decision } \\ 153 & 147 & - & - & - & 3.58 & \text { Accepted } \\ 98 & 241 & - & - & 38 & 3,85 & \text { Accepted } \\ 121 & 158 & - & - & 98 & 3.28 & \text { Accepted } \\ 97 & 260 & 10 & - & 10 & 4.15 & \text { Accepted } \\ 32 & 271 & 04 & 35 & 35 & 3.57 & \text { Accepted } \\ - & 291 & - & 36 & 41 & 4.05 & \text { Accepted } \\ 2 & 268 & - & 86 & - & 3.32 & \text { Accepted } \\ - & - & - & 299 & 78 & 1.79 & \text { Rejection } \\ 3 & 02 & - & 297 & 69 & 1.81 & \text { Rejection } \\ 9 & 30 & - & 288 & 50 & 2.09 & \text { Rejection } \\ 66 & 211 & - & 100 & - & 3.64 & \text { Accepted } \\ 78 & 199 & - & 100 & - & 3.67 & \text { Accepted } \\ 69 & 201 & - & 105 & 02 & 3.61 & \text { Accepted } \\ 73 & 211 & - & 90 & 03 & 3.69 & \text { Accepted } \\ 94 & 222 & 7 & 41 & 13 & 3.90 & \text { Accepted } \\ 11 & 42 & - & 234 & 90 & 2.07 & \text { Rejected } \\ 101 & 249 & - & - & 27 & 4.05 & \text { Accepted }\end{array}$

Table 3: Media Advocacy and Self-littering of the Environment

S/N

1. There is no need to have media advocacy on self-littering of the environment.

2. Media advocacy campaigns can only help in a little way to influence the public against self-littering habit.

3. Media advocacy is significant for discouraging of self littering of the environment.

4. Media advocacy should be consistent in order to stop self-littering of the environment.

5. Many Nigerians do not have self-regulatory on littering of the environment.

6. Poor environmental attitude is the greatest cause of self-littering.

7. There is inadequate media advocacy or education to discourage self-littering of the environment.

Mean point/benchmark:3.00

$\begin{array}{ccccccc}\text { SA } & \text { A } & \text { UD } & \text { DA } & \text { SD } & \text { Mean } & \text { Decision } \\ 35 & 38 & - & 215 & 89 & 2.24 & \text { Rejection } \\ & & & & & & \text { Accepted } \\ 58 & 299 & - & - & 20 & 3.99 & \\ & & & & & & \text { Accepted } \\ 241 & 136 & - & - & - & 4.63 & \\ & & & & & & \text { Accepted } \\ 211 & 156 & - & 10 & - & 4.50 & \\ 101 & 100 & - & 111 & 65 & 3.16 & \text { Accepted } \\ 211 & 166 & - & - & - & 4.55 & \text { Accepted } \\ 168 & 177 & - & 32 & - & 4.27 & \text { Accepted }\end{array}$


Table 4: Media Advocacy Strategies on Self-Littering

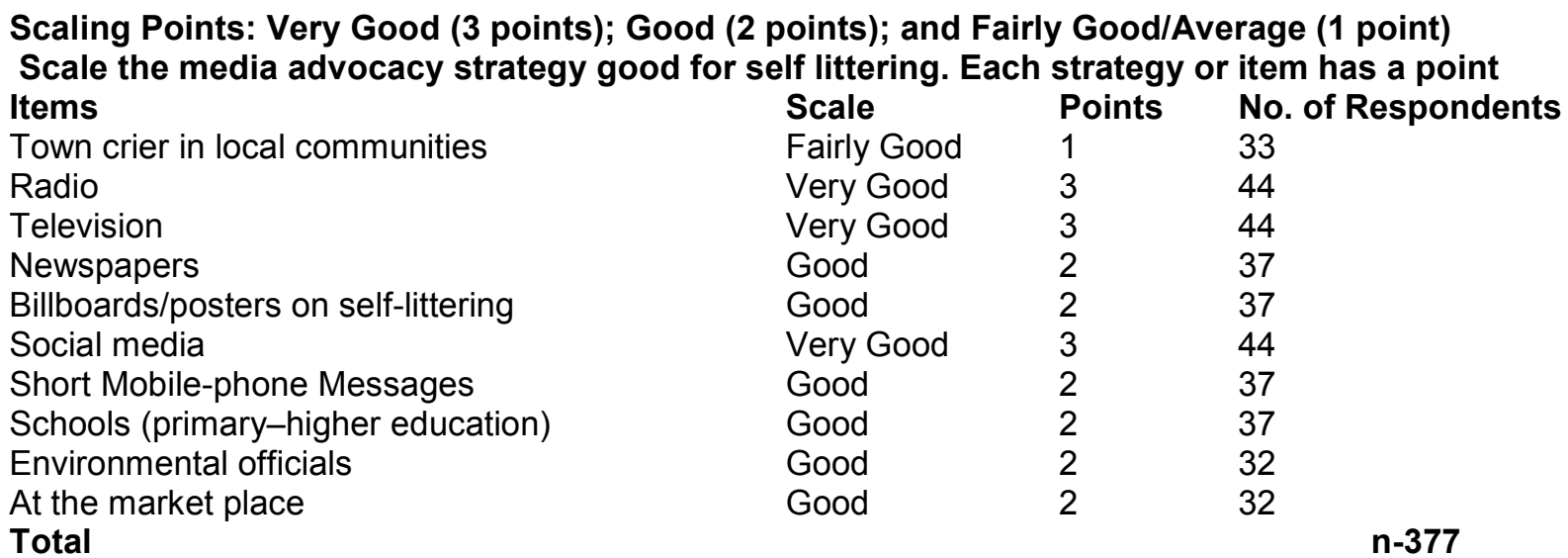

\section{Author's field work 2020}

This part is known as scaling point. In this table, respondents were expected to indicate by way of scaling the items or strategy good for discouraging self littering. Items or strategies that were good scaling 2 points were market place; environmental officials; schools (primary-higher education); small mobile messages; billboards or posters illustrating effect of self-litter; and newspapers. Town crier in local areas was indicated as fairly good or average scaling 1 point. Also, items or strategies scaled as 3 points were radio; television; and the social media. In all, the media of radio, television and the social media were scaled as very good strategies among others indicated to discourage self-littering of the environment. This does not in any way undermine the other strategies for advocacy against self-littering. All media advocacy strategies for discouraging self-littering are good depending on how it was used.

Table 5: Worries about Self-Littering of the Environment

\begin{tabular}{|c|c|c|c|c|c|}
\hline \multirow[b]{2}{*}{$\begin{array}{l}\text { How much are you } \\
\text { worried about...? }\end{array}$} & \multicolumn{3}{|c|}{ Options } & \multirow[b]{2}{*}{ Not worried } & \multirow[b]{2}{*}{$\begin{array}{l}\text { Not worried } \\
\text { at all }\end{array}$} \\
\hline & $\begin{array}{l}\text { Very } \\
\text { worried }\end{array}$ & Worried & $\begin{array}{l}\text { Not very } \\
\text { worried }\end{array}$ & & \\
\hline $\begin{array}{l}\text { Too much waste in } \\
\text { our environment. }\end{array}$ & $121(32.1 \%)$ & $256(67.9 \%)$ & - & - & - \\
\hline $\begin{array}{l}\text { Inappropriate littering } \\
\text { in our streets/roads. }\end{array}$ & $267(70.8 \%)$ & & $110(29.2 \%)$ & & - \\
\hline $\begin{array}{l}\text { Inappropriate waste } \\
\text { disposal habit }\end{array}$ & & $106(28.1 \%)$ & & $271(71.8 \%)$ & - \\
\hline $\begin{array}{l}\text { Throwing of used } \\
\text { packs or items from } \\
\text { a moving vehicle. }\end{array}$ & & $201(53.3 \%)$ & - & - & $176(46.6 \%)$ \\
\hline $\begin{array}{l}\text { Dirty environment as } \\
\text { a result of self- } \\
\text { littering }\end{array}$ & $148(38.2 \%)$ & $229(60.7 \%)$ & - & - & - \\
\hline $\begin{array}{l}\text { Poor environmental } \\
\text { attitude to waste } \\
\text { management. }\end{array}$ & & $231(61.3 \%)$ & $-146(38.7 \%)$ & - & - \\
\hline
\end{tabular}




\section{DISCUSSION OF RESULTS}

The three hundred and eighty four (384) sample size for the study was administered but three hundred and seventy-seven (377) copies were returned. This represented $98.2 \%$. The data collected through the questionnaire were pooled and analysed using descriptive statistics of frequency counts, percentage and mean. Though there were no tables for socio-demographics, the sample size returned (377) consisted of 211 male respondents representing $59.9 \%$ and 166 female respondents representing $44.0 \%$. In the age ranges, ages between 18-27 were 78 representing $20.6 \%$ of the respondents; between 28-37 were 62 representing $16.4 \%$ of the respondents; those between 37-46 were 102 representing $27.1 \%$ of the respondents; and those from 47 years and above were 135 representing $35.8 \%$ of the respondents. There were 121 representing $32.1 \%$ that were singles and 256 representing $67.9 \%$ that were married. On educational level, 291 (77.2\%) of the respondents had higher education while 86 $(22.8 \%)$ had primary education. The data also showed that there were 93 of the respondents representing $24.6 \%$ were students while 284 of the respondents representing $75.3 \%$ were in other occupations namely civil service; traders; teachers; artisans; health workers as indicated in the retrieved questionnaire.

Objective one was to examine respondents' personal awareness on self-littering of the environment. Self-littering of the environment is common practice in Nigeria. Many Nigerians are either aware or unaware of this bad environment habit. The awareness here does not generate from the mass media but out of personal consciousness and knowledge or concern. Many Nigerians are aware that they self-littered the environment. As shown, $67 \%$ of the respondents consciously littered the environment. This means that many Nigerians are aware that they consciously self-littered the environment by throwing waste or used items on the ground instead of the trash can or container or the appropriate place. As shown by $77 \%$ of the respondents, Nigerians still throw waste or used items from moving vehicle. This is a regular practice that should be discouraged by media advocacy and all. As earlier established, selflittering has become a culture to some individuals. Many Nigerians do not have proper littering habit or culture. They throw empty sachet water, banana peels, bottle or table water, and cob of maize, papers and all sorts of dirt on the ground in schools, colleges, and shops, on the streets, churches, motor-parks and other public places.

It is sad to note that $79 \%$ of the participants were not aware that self-littering constitutes environmental hazards like diseases as well as $73 \%$ of them were not aware that self-littering defaces the aesthetic beauty of the environment. This is a situation of poor environmental education or advocacy and poor environmental consciousness and concern. There is need therefore for environmental education. Ibimilua (2015) sees environmental education as a useful tool for the enhancement of good quality of life. It is a major instrument for the achievement of sustainable development. To Aina (1990), environmental education is that which aims at developing a world population that is aware of and concerned about the environment and its associated problems, and which has the knowledge, skills, attitudes and motivations collectively directed towards the solution of current problems and the prevention of new ones. Environmental education brings about environmental management. This is why Aina (1990) notes that environmental education connotes the thinking about the environment, knowledge, attitude and participation in environmental management and sustainability. The situation implies that perceptions, attitudes and general ignorance about the health and environmental are consequences of self-littering (Fearon \& Adraki, 2014).

It is worthy of note that $72 \%$ of the participants were aware that media advocacy is necessary to discourage self-littering. It should be noted that some of the respondents on one-to-one discussion with one of the research assistants said that SPEED FM in Benin City have regular calls on the need to clear wastes from gutters in order to prevent floods. This is done in Pidgin English: "Remember to clear dirty from gutter". We were made to understand that the station (SPEED FM) had environmental-phone-in programmes every Monday by 8:30am to 9am. There is another programme called "Area Matter" that comes on air the same Monday to Wednesday by $09 \mathrm{am}$ to $10 \mathrm{am}$. The programme is phone-in call that dwells on social matters in the community like environmental sanitation, security, education, electricity and roads. Other stations involved in environmental-phone-in 
discussion were Independent Radio (radio arm of Independent Television) and Edo Broadcasting Service. We were told that SPEED FM among other radio stations had been very consistent in environmental education on cleaning of the environment and waste management.

Objective two was to find out causes or reasons for self-littering of the environment, which has become a waste disposal habit among some Nigerians. Table 2 provided answers to this. The result showed that causes of self-littering of the environment among others include poor environmental culture from home; unconcern about the healthy environment; poor environmental management attitude; low level of environmental education and poor and inconsistent media sensitization. These causes imply one thing: poor environmental attitude. Eneji et. al. (2017) argued that people do not see the need to change their negative attitude towards littering. They play passive role in sanitation activities and refuse to co-operate with others in cleaning up residential surroundings because of their negative attitude.. Oluyinka and Balogun (2013) study had shown poor selfmonitoring attitude towards self-littering. This result corresponds with that of Eneji; Eneji; Ngoka, and Abang, (2017) that self-littering is a negative attitude which significantly influences health status of residents of Calabar South in Nigeria.

Objective three was determine adopted media advocacy strategies in discouraging of selflittering of the environment in Nigeria. All the items in Table 3 showed that media advocacy campaigns can help in a little way to influence the public against self-littering habit. By implication, media advocacy is significant for discouraging of self littering of the environment only when there are consistent environmental media advocacy strategies as shown in Table 4 . Consistent environmental media advocacy or education can be done in the strategy of town crier, radio and television education, newspapers articles, billboards and posters display or illustrating the effect of littering, social media, schools from the primary to higher education and other channels. This also explains the significance of media advocacy to discourage or stop self-littering habit. Media advocacy is significant in self-littering habit because it seeks a environmental behaviour change (Eze, 2014). By critically interpreting the messages and values of public health offered by the media, media advocacy can shape people's beliefs, values and attitude towards stopping of littering of the environment with all kinds of wastes. It is only when an individual is worried about littering of waste in the environment that self-littering can stop. This finding had been buttressed long ago by Eze. (2014) that media advocacy starts from an individual or members of a small, community-based health organization to the largest state or federal government health agency. As shown in Table 5, the extent an individual is worried about littering of waste determines the extent of behaviour change. This is an indication of waste management.

The theory use for this study finds credence with the results of this study. The theory of reasoned action states that individual intention is determine by the reasons of his actions. According to the theory, intention to perform certain behaviour precedes the actual behaviour. In other words, our intention determines our reason of an action or behaviour. The study had showed that self littering of the environment by individual is as a result of unconcerned intention and attitude towards the environment. Attitude and behaviour towards something is guided by our intention or behaviour. Behaviour sprouts from our intention or motives. When inhabitants' adopt reasons and actions that are in conformity with environmental values, and avoid actions that are harmful to the environment, then, littering of the environment would be reduced or controlled. The value we attach to the environment determines our attitude and behaviour towards self-littering which has become a disposal habit among many Nigerians.

\section{Implication of the findings}

Arising from the above, the findings imply that:

- $\quad$ Self littering of the environment has become a waste disposal habit among many Nigerians

- $\quad$ Self littering of the environment is as a result of unconcerned environmental management; poor environmental attitude, and low level of environmental media education or advocacy.

- $\quad$ Self littering of the environment should be discouraged by media education.

- In all, the study points to responsible or right environmental attitude and behaviour. 
Conclusion and recommendations

Self-littering has become a culture to some individuals. Nigerians do not have proper littering habit or culture. Nigerians still throw waste or used items anywhere on the ground and even from moving vehicle. This is a regular practice that should be discouraged by media advocacy and all. For this reason, there is need for consistent media advocacy to stop self-littering of the environment. Consistent environmental media advocacy or education can be campaigned by town crier, in the mass media, social media, and other channels. With consistent campaigns on self littering, one's beliefs and attitudes can be reasoned in such a way that littering can be stopped.

\section{REFERENCES}

Agba, J.U; Abang, O; and Ugor, O. E., 2017. International Journal of International Relations, Media and Mass Communication. 3 (5), 1-18.

Aina, A. T., 1990 Health, Habitat and Underdevelopment in Nigeria. London International Institute of Environment and Development.

Ajzen, I., and Fishbein, M., 1980. Understanding attitudes and predicting social behaviour. Prentice- Hall, Upper Saddle River, New Jersey.

Akeh, G. I. and Shehu, B., 2018. Solid Waste Disposal and Management Problems in Ramat Polytechnic Maiduguri, North-East Nigeria. 3 (1). Journal of Ecology and Environmental Sciences. Retrieved $16^{\text {th }}$ July, 2019.

Akpan, C. S., 2006. Pillars of Broadcasting. Aba: Visual Impression.

Akpoghiran, I. P. and Okoro, F. E., 2017. Applicable theories to mass communication studies. Benin City: Socent Ebose Publisher.

Anozie, A. J., 2017. Attitude change in Lagosians: Responsible personal waste disposal. From Deutsche Welle Blogger.
Dorfman, L and Krasnow, I. D., 2014. Public

health and media advocacy. Annual Review of Public Health Publication. 35, 293-306. www.annualreviews.org

Dung, M. D.; Mankilik, M. and Ozoji, B. E., 2017. Assessment of college students' knowledge and attitudes towards solid waste management in north central zone of Nigeria. Science Education International ; 28 (2), 141-146.

Eneji, C. V. O; Eneji, J. E. O; Ngoka, V. N. and Abang, M., 2017. Attitude towards Waste Management and Disposal Methods and the Health Status of Cross River State, Nigeria. SCIREA Journal of Agriculture. 1 (2).

European Chapter for Media Literacy. Media Education www.Euromedialiteracy.eu

Eze, C. C., 2014. Media advocacy for sustainable water management in Africa: A study of Nigeria. WIT Transactions on Ecology and the Environment, vol 185, www.witpress.com .

Fayoyin, A., 2014. Media advocacy approaches of development agencies: Implications for journalism practice in developing countries. Asia Pacific Journal of Research. 1 (13), 50-62.

Fearon, J. and Adraki, P. K., 2014. Perceptions and attitudes to waste disposal: an assessment of waste disposal behaviours in the Tamale Metropolis. Journal of Environment and Earth Science. 4, (1). www.iiste.org.

Freijea, A. M; Nasera; H. A. and Abdullab, K. H., 2019. Attitudes and opinions towards public littering in the Kingdom of Bahrain. Arabic Journal of Basic and Applied Sciences 26 (1); 354-361. A publication of Taylor and Francis

Gamba, R., and Oskamp, S., 1994. Factors influencing community residents participation in commingled curbside recycling programs. Environment and Behaviour, 26, 587-612. 
Ibimilua, A. F., 2015. The what, why and how of environmental education. International Journal of Education and Research. 3 (1), $25-38$.

Ifegbesan, A., 2009. Exploring secondary school students' understanding and practices of waste management in Ogun State, Nigeria. In International journal of environmental education. 5(2), 201-215. www.ijese.com/

Madden, T. J., and Ajzen, I., 1986. Prediction of goal-directed behaviour: Attitudes, intentions and perceived behaviour control. Journal of Experimental Social Psychology, 22, 453-474.

Mamady, K., 2016. Factors influencing attitude, safety behaviour, and knowledge regarding household waste management in Guinea: A cross-sectional study. In M.K. C. Sridhar (Ed). Journal of Environmental and Public Health.

Nwabueze, C., 2007. Environmental communication: perspectives on green communication and information management. Enugu: Daisy Press.

Okaka, W; and Nagasha, I. J., 2017. Media advocacy communication campaign for effective climate change policy and research information service in Africa. A Research Gate Publication.

Oluyinka, O.; and Balogun, S. K., 2013. Selfmonitoring and responsible environmental behaviour: the mediating role of attitude towards littering. Frontiers in Psychological and Behavioral Science. 2 (1), 31-38.
Oteng-Ababio M., 2012. The role of the informal sector in solid waste management in the GAMA, Ghana: Challenges and opportunities. Econ Soc Geogr.

Oyesomi, K. O; Oyero, O; and Okorie, N., 2014. Media advocacy, development journalism and child right issues in Nigeria. Scholars Journal of Arts, Humanity and Social Sciences. 2 (2B), 261-265.

US Dep. Health Hum. Serv., 1988. Media strategies for smoking control. Washington, DC: Gov. Print. Off.

Waibord S., 2006. Advocacy journalism in a global context. In Wahl-Jorgensen $\mathrm{K}$ and Hanitzsh $T$ (Eds). The Handbook of Journalism Studies, Routledge. New York. 371-385.

Wallack, L 1994.Media Advocacy: A strategy for Empowering People and Communities. Journal of Public Health, 155(4) 420-36.

Wallack, L; Dorfman, L; Jernigan, D; ThembaNixon M., 1993. Media Advocacy and Public Health: Power for Prevention. Newbury Park, California, USA; Sage Publications.

Wever, R., Onselen, L., Silvester, S., and Boks, C., 2010. Influence of packaging design on littering and waste behaviour. Packaging Technology and Science, 23(5), 239-252.

Yoada, R. M; Chirawurah, D. and Adongo, P. B., 2014. Domestic waste disposal practice and perceptions of private sector waste management in urban Accra. An online publication of Bio-Med Central for Public Health. 